\section{O poder do}

\section{matrimônio no}

Medievo:

\section{repercussões sobre 0 \\ controle do homem, \\ da mulher e a \\ sociedade de títulos.}

\section{Ana Clara Cordeiro de Oliveira*}

DOI: 10.11606/issn.2318-8855.v10i2p416-438

Resumo: O poder na Idade Média permite um campo de pesquisa muito além das ações políticas, pois ao alargar o horizonte conceitual é percebido uma alta complexidade que deve ser compreendida também a partir de poderes culturais e sociais, expandindo para outras dimensões e as interligando. Com isso, a ideia do artigo é trazer a temática do poder dentro dessa perspectiva mais abrangente, sendo escolhido o matrimônio como exemplo, já que o mesmo teve um forte papel de controle social, modulando as condutas tanto dos homens como das mulheres; servindo de proteção para a maliciosidade feminina; tocando na questão da sexualidade humana, de forma que a regulasse e julgasse. O casamento também teve o papel de dar sustento ao sistema aristocrático medieval, pois alimentava os princípios de hereditariedade, das linhagens e dos títulos sociais. Portanto, o casamento, monogâmico e indissolúvel, e os títulos aristocráticos são elementos essenciais para a estruturação do imaginário matrimonial da Idade Média, em que se inclui a Igreja e o Estado, posto que estavam enraizados tão fortemente no mundo ocidental. Ademais, esse imaginário negativo sobre a figura feminina e sobre as ideias impostas à instituição do matrimônio podem ser percebidos nos discursos conservados e religiosos do Brasil atual.

Palavras-chave: Casamento, Controle, Idade Média, Nobreza, Sexualidade.

* Graduanda em História na Universidade do Estado do Rio de Janeiro. E-mail: anaclaracordei@gmail.com 


\section{O poder na Idade Média}

Ana Clara Cordeiro de Oliveira

\section{Introdução}

Antes de se abarcar o tema real desse artigo “O poder do matrimônio no Medievo" chamo a atenção para a importância de se estar incentivando graduandos e graduados brasileiros à pesquisa no campo temporal da Idade Média, pois como o medievalista Hilário Franco Júnior (2008) afirmava, as raízes do Brasil se fincam e foram influenciadas mais profundamente pelo período Medieval do que Moderno, portanto, nesse sentido, estudar o Medievo também é uma forma de compreensão da cultura brasileira. Sobre isso, fica aqui a gratidão de ter a oportunidade de discutir, mesmo que de forma pontual, o poder nesse período histórico.

Ao se debruçar sobre a temática do casamento no Ocidente Cristão Medieval, optou-se por um recorte temporal alargado e pela dimensão espacial mais abrangente, pois foi uma instituição com presença em todas as sociedades europeias cristãs do Medievo, mesmo contendo certas diferenças, e que não teve um momento definido de formação, mas foi se construindo e alterando-se ao longo da história, tomando partidos e funções crucias para o sustento das sociedades. E por isso, com relação à temporalidade, o presente artigo se contentará em discutir o poder do matrimônio na época da Baixa Idade Média, séculos XI ao XV, pois foi o momento em que estava sendo desenvolvida uma teologia e uma moral do casamento. Enquanto o campo espacial escolhido foi o Ocidente europeu cristão, que é exatamente onde acontecem essas discussões.

É importante deixar claro que certamente não é o objetivo do artigo homogeneizar a Idade Média no que se refere a sua perspectiva sobre o matrimônio, pois as suas organizações tinham particularidades, assim como a rigidez que seguiam na prática, variando de lugar para lugar e de época para época. Entretanto, de forma geral, os pontos discutidos nesse trabalho podem ser visualizados e identificados 


\section{O poder na Idade Média}

O poder do matrimônio no Medievo

nesse espaço e recorte temporal escolhidos para a discussão.

Em relação à eleição do poder do casamento como tema, foi feita a partir de uma análise mais abrangente da sociedade medieval, buscando não só exemplos políticos, mas também poderes culturais e sociais, expandindo para outras dimensões e as interligando. A temática, portanto, compromete-se com uma abordagem teórica e metodológica da Nova História Cultural, herdeira da Escola dos Annales, que parte da compreensão da realidade sobre o fato estudado a partir das representações produzidas por sujeitos: fotos; filmes; depoimentos; desenhos, gerando uma enorme gama de visões sobre um determinado fato, tendo o historiador o papel de recolher esses diferentes olhares e cruzá-los, formando uma inteligibilidade do que possa ter acontecido.

Ao discutir o casamento e seu poder na sociedade Medieval, se torna necessário trazer algumas ressalvas feitas por Georges Duby (1989) em sua obra "Idade Média, Idade dos Homens", essas destinadas aos historiadores, de que os mesmos não poderiam se ater exclusivamente aos enunciados normativos e aos regulamentos jurídicos, acreditando que as palavras escritas efetivamente governaram o comportamento dos homens. Nesse sentido, o historiador cairá na ilusão se acreditar sem precauções no que os escritos eclesiásticos declaravam, partilhando do pessimismo e da ironia ao colocar como verdade o que esses documentos expressavam sobre a realidade conjugal. Portanto, Georges Duby alertou sobre as preocupações e os cuidados que o historiador deve ter com as fontes religiosas sobre o matrimônio, assim como, em relação ao leitor interessado, em que também se alerta uma necessária problematização para que ocorra uma boa compreensão da temática. 


\section{O poder na Idade Média}

\section{Ana Clara Cordeiro de Oliveira}

Além disso, é preciso deixar claro que o campo social analisado é o da nobreza, pois ao traçar a evolução da prática do casamento, é reconhecido a sua maior utilidade e função na chamada "boa sociedade", aquela dos príncipes e cavaleiros. Logo, as repercussões dos códigos matrimoniais sobre as camadas mais pobres do Medievo não foram pontos centrais desse artigo. Contudo, seria passível incorrer em incompletude, se, em momentos, não houvesse rápidas observações sobre a questão, já que são enormes as chances de terem também afetado essas classes subalternas.

Após essas ressalvas, retomamos a afirmação anterior de que o poder no mundo Medieval não deve ser compreendido somente a partir de uma perspectiva política, pois a sua presença está contida em diversos campos da estrutura do Medievo, entre eles o cultural. Partindo dessa ideia, o artigo abordará o poder do matrimônio destacando a sua forte influência na estruturação do mundo Medieval, recorrendo de início a uma breve história da sua formação, em que havia uma disputa entre os ideais laicos e religiosos em relação ao domínio dos códigos. Em um segundo momento, irá reconhecer o papel do matrimônio como instituição reguladora, estimulado pelos clérigos, sobre o comportamento dos homens e principalmente das mulheres, controlando a sexualidade e as condutas sociais. Em um terceiro momento, discutiremos a importância do casamento no funcionamento da estrutura aristocrática, como sustentador da questão da linhagem, da terra e do poder social.

\section{Desenvolvimento}

\subsection{O conflito entre o secular e o espiritual}

A Idade Média, desde o início, foi marcada por uma disputa entre os valores temporais e espirituais, ocasionada pelo desejo da Igreja de se estabelecer nos novos 


\section{O poder na Idade Média}

\section{O poder do matrimônio no Medievo}

tempos, partilhando do poder com os laicos. O papa Gelásio I', um dos mais importantes do período Medieval, escreveu em sua epístola de 492 sobre a existência de dois poderes: a Igreja e o Império. Um trecho dessa obra destinada ao imperador Anastácio resume bem essa questão, como atesta José Antônio Souza (1995, p.85-86):

Augusto imperador, são principalmente dois os poderes através dos quais se governa o mundo: a autoridade [auctoritas] sagrada dos pontífices e o poder [potestas] real. Destes dois, é mais grave o peso dos sacerdotes, pois estes deverão prestar contas na ocasião do julgamento divino, inclusive pelos próprios reis da humanidade.

Na verdade, tu sabes, filho clementíssimo, que em razão de tua dignidade és o primeiro de todos os homens e o imperador do mundo, todavia se submisso aos representantes da religião e suplica-lhes o que é indispensável para tua salvação.

Com efeito, no que se refere à administração dos sacramentos e à disposição das coisas sagradas, reconhece que deves submeter-te à sua orientação e não seres tu quem deva governá-lo, e assim nas coisas da religião deves submeterte ao seu julgamento e não querer que eles se submetam ao teu. Ora, no tocante ao governo da administração pública, os próprios sacerdotes, cientes de que o poder te foi conferido pela vontade divina, obedecem às tuas leis, pois no que se refere às coisas do mundo não lhes agrada seguir orientação diferente.

A partir dessas teses, são conhecidas as ideias que circulavam pelas mentes do poder da época, marcadas pela noção de que havia um projeto de inserção dos valores espirituais e a existência paralela dos mesmos com os valores leigos, cenário que repercutiu em outros espaços e instituições de escala privada, entre elas na disputa do controle do sistema matrimonial.

Durante os seus primórdios, a Igreja Católica reconhecia o casamento como uma relação condenável e pecaminosa, pois afirmava que o mesmo era um empecilho para o ato de contemplação da vida espiritual, deixando espaço para que

\footnotetext{
${ }^{1}$ Nascido na África no ano de 410, foi papa de 1 março de 492, até a data de sua morte, em 21 de novembro de 496.
} 


\section{O poder na Idade Média}

Ana Clara Cordeiro de Oliveira

os costumes laicos construíssem o sistema matrimonial.

Porém, ao perceber que estava perdendo influência e poder, a necessidade de se inserir no seio da estrutura Medieval se tornou maior. Com isso, a Igreja modificou em parte essa visão, reconhecendo que seria impossível proibir o homem da necessidade que tem de copular para se reproduzir, pois esses anseios são consequências do Pecado Original de Adão e Eva. Com isso, a Igreja, pautada no mandamento "crescei e multiplicai-vos" (GÊNESIS, 1:28, 9:7), admitiu o matrimônio como um mal menor e se serviu dele para ampliar o seu poder e controle social. A partir disso, afirma Georges Duby (1989), o modelo proposto pelos clérigos conviveu em paralelo com a estrutura já em voga baseada em valores temporais e seguida nas casas aristocráticas.

Todavia, para que isso acontecesse e o compromisso matrimonial perdesse o valor pecaminoso e fosse incentivado pela Igreja, foi necessário criar regras comportamentais entre os cônjuges, limitando o contato entre os corpos, declarando os sentimentos permitidos, as posições sexuais aceitáveis e, até mesmo, a frequência do ato, sendo a paixão entre o casal totalmente condenável. O historiador francês Jacques Rossiaud (2006, p. 480) abordou essa questão em sua obra "Sexualidade", resgatando as visões que os eclesiásticos possuíam sobre o ato sexual, tendo que os cônjuges:

Limitar-se às relações noturnas, esquivar-se da nudez e não provocar volúpia por gestos, cantos ou atitudes impudicas. Recomenda-se não abusar da mesa, pois o excesso de carne e vinho inflama o desejo carnal. É necessário saber dominar os corpos a fim de reduzir o número de encontros. (...) Além disso, as posições incomuns são perigosas, provocam a cólera de Deus, ultrajam a ordem natural (como o equus eroticus), e podem dar lugar a concepções monstruosas (por exemplo, o acoplamento more canino). Ocorre o mesmo com o desrespeito aos períodos interditos, que totalizam, inicialmente, mais de 250 dias (...). 


\section{O poder na Idade Média}

O poder do matrimônio no Medievo

Mais tarde, após o Concílio de Latrão de 1215, os manuais de confissão começaram a ganhar ênfase, pois era onde se reuniam essas regras comportamentais, servindo como fontes para os clérigos julgarem e como regulamento para os leigos obedecerem. Um excelente exemplo é a obra “Libro de las confesiones", escrito pelo confessor Martin Pérez, que tinha a particularidade de se preocupar em atingir membros do baixo clero de pouca ciência e também leigos que não sabiam latim. Entretanto, e infelizmente, a obra do confessor não está completa aos pesquisadores, assim como nenhum dos códices são do seu livro original. Ainda assim, a mesma teve um grande número de edições posteriores, sendo um rico exemplo para se entender os comportamentos da época.

Com todos esses pontos, entende-se que a evolução do casamento é marcada por um início de condenação, como anteriormente falado, passando por diversas etapas de adaptação perante as ideias espirituais, que acabaram transformando o espaço conjugal em um ambiente em que se era permitido exercer de forma controlada a sexualidade humana tão fortemente temida pelos clérigos. Portanto, aos moldes da Igreja, o sistema matrimonial passou a carregar o poder de regulação do ato sexual, moralizando os costumes e comportamentos de todos aqueles propícios aos crimes da carne.

Chamo a atenção sobre a ideia anteriormente apresentada de "todos aqueles propícios ao crime da carne", pois provavelmente existe uma problemática em relação à participação de muitos membros dos setores mais pobres da sociedade, já que havia a necessidade de saber latim para entender esses códigos de controle, e que por isso, pode ter limitado a regulação religiosa sobre os casamentos além dos 


\section{O poder na Idade Média}

Ana Clara Cordeiro de Oliveira

feitos na nobreza. Portanto, ao se discutir sobre o matrimônio, é necessário ter em mente que os religiosos estavam construindo um imaginário social, este que dificilmente teria sido completamente implementado na prática.

Ao fim, a relação matrimonial tem seu ritual sacralizado, representando a supremacia dos eclesiásticos sobre o modelo dos leigos, não se limitando ao controle do casamento, mas sendo exemplo de uma conjuntura presente, em que ocorria um intenso processo de cristianização das estruturas. Esse modelo acabou por solidificar uma sociedade em ordens, em que cada pessoa pertencia a uma determinada categoria destinada por Deus. Em relação a essas ideias, Silvana Vecchio (1990, p.144):

A definição da natureza sacramental do matrimônio marca não só a conclusão de um longo debate teológico, mas também o triunfo do modelo eclesiástico. À literatura pastoral compete a tarefa de difundir e popularizar, eliminando-lhe as sutilezas teológicas, a nova doutrina matrimonial, e, ao mesmo tempo, de inventar uma pedagogia e uma moral da família que tenham em conta os valores da escolha conjugal.

\subsection{Visão religiosa: O poder do casamento sobre o homem e a mulher}

Durante o século XII, os homens da Igreja começaram a falar sobre diversas questões da ordem social, buscando reformar a moral da sociedade. Dessas questões, as centrais eram: a origem da humanidade e o papel dos homens e das mulheres no mundo cristão. Para obter as respostas, recorreram ao livro do Gênesis, aquele que segundo Georges Duby (2001, p.45) "relata a origem do gênero humano, a fundação da ordem moral, da ordem social e fornece, em algumas frases, uma explicação global da condição humana". A partir dessa fonte, diversas interpretações foram feitas por padres e religiosos, que foram a base para a construção de uma imagética feminina relacionada ao pecado e de inferioridade ao homem, que deram origem aos códigos matrimoniais. 


\section{O poder na Idade Média}

O poder do matrimônio no Medievo

A partir do livro do Gênesis, os padres retiraram dois modelos de feminilidades: Lilith e Eva, ambas tinham sido esposas de Adão. A primeira era retratada como rebelde e insubmissa, e por isso foi substituída por Eva, criada para ser submissa ao marido. Entretanto, Eva acaba não correspondendo ao seu dever, agindo de forma orgulhosa ao convencer Adão de provar do fruto proibido, desobedecendo a Deus, e colocando a humanidade em uma maldição. Com isso, as mulheres acabaram sendo categorizadas como descontroláveis, conversadeiras, desobedientes e sedutoras.

Além disso, a imagem de que a mulher seria inferior ao homem também ganhou sustento com a história de Eva, pois a mesma teria nascido da costela de Adão, como uma espécie de subproduto da criação, enquanto o homem teria sido criado diretamente por Deus, a partir de um sopro divino. Logo, tanto Eva quanto todas as suas descendentes eram inferiores ao homem, por terem nascidas dele. Nessa mesma ideia, como a mulher se originou da carne, ela também estava mais próxima do sexo e do pecado, e por isso era perigosa e fonte de tentação.

A redenção dessas "Evas" acontece com o advento da exaltação do culto à Virgem Maria, pois a mesma teria sido um modelo de mulher que foi capaz de conceber sem pecar, não havendo prazer sexual. A mãe de Jesus era um exemplo de feminilidade que se baseava na assexualidade do feminino e na sua pureza, tendo conseguido reparar o pecado original causado por Eva. Logo, o modelo mariano foi fortemente incentivado e implantado pelos padres da Igreja, mesmo tendo em mente que era apenas um ideal, impossível ao alcance das mulheres comuns.

Portanto, as mulheres, ao exemplo da Virgem Maria, deveriam ter como ideal a virgindade, vivendo em conventos. Entretanto, se a mulher não conseguisse atender a essa castidade, eram incentivadas ao casamento, pois assim poderiam servir ao seu 


\section{O poder na Idade Média}

Ana Clara Cordeiro de Oliveira

marido e ter filhos, já que a redenção a partir de Maria não mudou a ideia de que a mulher era inferior ao homem, e que por isso deveria se submeter às suas ordens. Como afirmou Rodolpho Bastos (2017, p.12), "enquanto em Eva as mulheres são reprimidas, através de Maria elas são controladas".

As mulheres, ou melhor, as fontes de pecado estavam por todos os lados, sendo difícil resistir à tentação. E por isso, o casamento começou a ser fortemente incentivado como uma forma de defesa para os homens. Como declarou São Paulo: “O melhor é o homem não tocar a mulher. Todavia, para evitar a formicação, tenha cada homem a sua mulher e cada mulher o seu marido" (1 Cor. 7: 1-3). Com isso, o casamento se tornou o sétimo sacramento pelas autoridades da Igreja (DUBY, 2001, p.55).

O código matrimonial formulado pelos clérigos teve o importante papel de configurar as condutas dos homens e principalmente das mulheres, impondo o comportamento aceitável e controlando principalmente sua sexualidade. De acordo com Carla Casagrande (1990), a ideologia dos eclesiásticos tinha de modo consensual a mulher como um ser frágil, e que, por isso, deveria viver sob a tutela de algum homem, podendo ser seu pai, irmão e esposo, recebendo em troca sua proteção e sustento. Um trecho da autora Carla Casagrande (1990, p.122) explica bem essa ideia:

As mulheres não podem, portanto, guardar-se sozinhas; a infirmitas de sua condição, que as torna débeis e privadas de toda a firmeza, exige que ao lado do pudor intervenham outras defesas. (...) Os homens - pais, maridos, irmãos, pregadores, directores espirituais - partilham com Deus e com os sistemas jurídicos o difícil, mas necessário encargo de <<guardar>> as mulheres; as quais, porém, afortunadamente (...) se unem para sempre submetidas à autoridade dos seus companheiros e, portanto, prontas, se não mesmo dispostas, a suportar-lhes a custódia. 


\section{O poder na Idade Média}

O poder do matrimônio no Medievo

Para a construção desses códigos, os padres se basearam na imagem da Virgem Maria, já que reconheciam as mulheres como seres naturalmente frágeis, doces e afetivas. Porém, ao mesmo tempo, afirmavam a necessidade de um adestramento do comportamento feminino, pois seriam descendentes de Eva, a causadora da Queda da Humanidade. Logo, essa imagem ambígua da mulher influenciou fortemente o papel da esposa no matrimônio, e antes que se torne confuso ao leitor, é avisado que essas contradições eram oriundas da própria sociedade Medieval cristã, a partir do século XII.

Antes que se casasse, a mulher era educada para ser uma boa esposa, aprendendo a agir de forma submissa e reservada, preocupando-se principalmente com a sua reputação e recusando qualquer vontade carnal, mantendo-se virgem. Quando chegasse o momento de escolher um pretendente, a sua voz era totalmente apagada, pois, além de ser comum na alta nobreza, os casamentos eram feitos a partir de acordos entre as casas e não por consentimento mútuo, a opinião feminina, portanto, era irrelevante.

Ao se casar, a mulher tinha a obrigação de cuidar da casa, passando a maior parte do seu tempo dentro da mesma, organizando-a e deixando a moradia em ordem, até a chegada do seu marido. Portanto, a esposa, ao modelo da Virgem, não trabalhava fora de casa e muito menos estudava para ter uma profissão. Entretanto, é nesse momento que a problematização necessária aparece, avisada anteriormente, pois, as mulheres que não eram de famílias ricas dificilmente se encaixavam nessas condutas, já que provavelmente não podiam se dar ao luxo de não trabalhar, porque precisavam comer e ajudar a sustentar sua família. Logo, chama-se a atenção sobre esses códigos serem parte de um imaginário construído, e não necessariamente a realidade. 


\section{O poder na Idade Média}

\section{Ana Clara Cordeiro de Oliveira}

A outra obrigação da esposa era de reproduzir, pois fazia parte do seu castigo divino dar à luz aos filhos dos homens e sentir dor por isso. Assim como também era a sua punição, ser dominada pelo seu marido, se submetendo a todas as suas ordens. Logo, por ser o castigo designado por Deus, a dominação do homem sobre a esposa se tornava inquestionável e totalmente legítima.

Na obra, História das Mulheres no Ocidente, Silvana Vecchio (1998) chama a atenção para o duplo papel de pacificação que a mulher casada carregava, já que a mesma deveria ser a paz para o marido, agindo de forma calma, subordinada e evitando que desentendimentos ocorressem, assim como deveria manter boas relações com os sogros e com os parentes de seu esposo, sendo respeitosa e pacífica, preservando acima de tudo a união familiar. Com isso, a mulher tinha a função de promover concórdia social, que era de suma importância para manutenção do casamento e de toda estrutura Medieval. Entretanto, é preciso entender que essa "maturidade" da mulher não era vista como uma atitude superior ou que a elevasse, mas era uma função que ampliava sua subordinação.

Somando-se a isso, no sistema matrimonial eclesiástico, a figura central da vida da mulher deveria ser o homem, devendo se subordinar e fazer o que fosse necessário para manter a relação. Quanto ao homem, de acordo com Silvana Vecchio (1990), jamais deveria se permitir ficar cego pela paixão, ou ainda colocar a mulher como o centro do seu mundo, pois as mulheres são como eternas Evas, buscando o prazer sexual e a dominação do homem. Thomas Malory² (2005), ao escrever sobre o casamento de Arthur e Ginebra ${ }^{34}$, em sua obra La muerte de Arturo, retrata uma

\footnotetext{
${ }^{2}$ Thomas Malory foi um romancista inglês, que ficou conhecido, principalmente, após escrever a obra Le Morte d'Arthur, vista como um dos principais livros sobre as histórias do rei Artur e dos Cavaleiros da Távola Redonda.

${ }^{3}$ A rainha também tinha o nome de Guinevere.
} 


\section{O poder na Idade Média}

O poder do matrimônio no Medievo

situação similar, em que o Rei alimenta uma grande paixão pela esposa. Por Ginebra ser a figura central da sua vida, a mesma acabou causando a queda do seu reinado, na medida em que Arthur não conseguiu lidar com a traição da sua esposa com seu amigo Lancelot.

Em relação aos homens, os códigos matrimoniais também regularam as suas condutas, já que eles necessitavam controlar os seus impulsos carnais, e inclusive serem vigilantes dos seus desejos mais profundos, pois como anteriormente falado, lidavam a todo tempo com as tentadoras Evas, que estavam em variados lugares.

Portanto, o homem, mesmo que não fosse tão vigiado quanto a mulher, precisava seguir um caminho livre de prazeres carnais, e isso se enquadra tanto antes quanto depois de se casar. Pois antes que conseguisse uma esposa, na visão desses religiosos, ele deveria se manter distante das perigosas mulheres, tendo uma intimidade somente com a sua esposa e exclusivamente com o objetivo de se reproduzir. Entretanto, não era o que algumas vezes acontecia, pois eram comuns os ritos de sociabilidade aristocrática, que consistiam em um jogo educativo ao incentivar os valores viris e cavaleirescos aos jovens solteiros, sendo a mulher o centro de rivalidades entre os homens e, também, o prêmio das competições.

Além disso, como a consequência da Queda da humanidade não se restringiu a Adão e Eva, todos os seres humanos foram punidos por Deus. Logo, os homens também tinham o seu castigo divino, que era de ser condenado ao trabalho pesado e a responsabilidade sobre o sustento da sua família. Essa punição parece questionável quando se pensa na nobreza Medieval, em que o "pesado" talvez não seja o que realmente faziam. Provavelmente, nesse momento, o imaginário cairia melhor na realidade dos homens pobres. 


\section{O poder na Idade Média}

\section{Ana Clara Cordeiro de Oliveira}

Somando-se a isso, nos códigos matrimoniais era obrigatório que ambos os cônjuges mantivessem a sua fidelidade, não devendo, portanto se corromper com tentações externas. Entretanto, como o próprio Georges Duby (1989) chamou atenção, é preciso ter em mente que muitas vezes a prática era diferente da moral instituída, já que a sexualidade masculina não se restringia ao laço conjugal, tendo sido comum homens satisfazerem-se com suas esposas e com outras mulheres fora de casa. Além de traições, a ideia de que a sociedade Medieval na prática era estritamente monogâmica também é um exemplo dos equívocos que Georges Duby estava falando, pois na realidade era costume as trocas de esposas.

A desigualdade entre os papéis que a mulher e o homem desempenhavam na vida conjugal era enorme. Sobre isso, o matrimônio era baseado em uma desigualdade natural, pois ao contrário da mulher, o homem não era visto como um ser inferior e submisso à sua esposa. Isso acontece pela interpretação extraída do Livro dos Gênesis, feita pelos padres da Igreja, baseada na origem de Eva a partir da costela de Adão, e também as condutas pecadoras das suas duas esposas, culpadas por toda maldade no mundo. Logo, mesmo que o marido também tivesse suas condutas controladas e sofrido um castigo divino, a figura feminina era mais cobrada e vigiada, pois a mácula do Pecado Original recaiu principalmente sobre as mulheres.

A partir dessas diferenças entre os gêneros, é entendido que o código matrimonial imposto pelos eclesiásticos era mais uma forma de dessexualizar a mulher, pois, como a própria Silvana Vecchio afirmava (1990), a mulher casada era a base de toda organização comportamental da moral dos religiosos. Logo, mesmo que os homens também tivessem que controlar suas vontades carnais, na visão desses padres, o masculino era principalmente disciplinado a partir da própria administração do comportamento feminino, pois controlando as fontes de tentação, seria difícil 


\section{O poder na Idade Média}

O poder do matrimônio no Medievo

existir possibilidades para o pecado masculino. Um trecho de Kaplisch- Zuber (2006, p.139) explica bem essas questões:

Na Idade Média não se concebe a ordem sem a hierarquia. A construção do masculino/feminino respeita esta noção e se esforça em articular entre eles os dois princípios da polaridade e da superposição hierarquizada, quer dizer, uma classificação binária e horizontal, fundamentada na oposição, e uma interdependência vertical entre categorias. Desta difícil combinação resulta uma imagem negativa e inferior do feminino na sua relação com o masculino.

O medo da feminilidade era tão grande que levou os moralistas da Igreja a desenvolverem um movimento pastoral com o objetivo de orientar espiritualmente as mulheres, pois a compostura feminina deveria ser assegurada a qualquer preço, inclusive com penitências. Logo, o projeto eclesiástico poderia ser considerado mais como um saneamento do feminino, colocando sobre os homens os papéis de possíveis vítimas dessas tentações.

Com todas essas informações, é reconhecido e afirmado que o casamento foi um poder intrínseco à sociedade medieval, que pelo menos na teoria, teria dominado a moral que regulava os comportamentos sociais, designando as funções e as condutas dos homens e, principalmente, das mulheres, em que estas que foram coagidas e depreciadas por uma construção ideológica religiosa, sustentada pelo que de maior valor existia no sistema medieval: a crença.

\subsection{Visão laica: o casamento no mundo aristocrático}

Ao analisar a trajetória do matrimônio, chegou-se à conclusão de que o casamento tinha sido formado por dois modelos: o religioso, que controlava as condutas dos homens e principalmente dessexualizava a mulher, e o leigo, que estruturava as práticas aristocráticas. Sobre o último, o objetivo principal concerne ao 


\section{O poder na Idade Média}

Ana Clara Cordeiro de Oliveira

viés material, se preocupando com a questão da hereditariedade, títulos sociais e bens familiares, que eram elementos base para a organização política, social e econômica da Idade Média.

O matrimônio na visão leiga era mais uma união entre famílias, baseada em acordos pré-nupciais, não havendo a necessidade de consentimento dos cônjuges. 0 objetivo era conseguir um casamento promissor que não corrompesse a posição da família, ou melhor, que a fizesse ascender de nível social. Lembrando que o sistema de títulos era o elemento base da sociedade Medieval, sem ele a estrutura desmoronaria, e a Idade Média que se entende hoje seria diferente. Por isso a importância do casamento, pois o mesmo tinha o poder de organizar essas relações, afirmando a posição social de uma pessoa e também sendo um caminho de possibilidade de ascensão.

O poder do casamento não recaía somente sobre os noivos, mas refletia em toda família, já que um matrimônio bem arranjado pelos pais era crucial quando fossem à "procura" de um marido ou esposa, pois seria levado em conta o histórico das linhagens, podendo tanto ajudar quanto atrapalhar o sucesso de "casar-se bem". Portanto, selar um compromisso era algo que precisava de muita cautela, porque um casamento mal feito de qualquer membro da família, optando, por exemplo, amar alguém inferior a eles, seria uma grande vergonha que mancharia a reputação de toda a linhagem, passada e futura. No trecho destacado, Georges Duby (1989, p.15) discute essa questão:

Na pessoa dessas crianças reúne-se o que ela trouxe [a mãe] e o que elas conservam de seu pai, a esperança de duas sucessões, a reverência para com duas linhagens de antepassados de onde são retirados, segundo regras de

difícil reconstituição, os nomes dados a cada uma delas. A posição que elas 


\section{O poder na Idade Média}

O poder do matrimônio no Medievo

ocuparão no mundo, as oportunidades que terão por sua vez de se casarem bem dependem das cláusulas da aliança concluída por ocasião do casamento dos seus pais.

A linhagem, portanto, era um fator de suma importância para a nobreza Medieval, pois era ela que determinava o status de uma família e o seu poder na sociedade. Um claro exemplo é a questão da realeza, em que o sangue determinava quem seria o rei e também a linha de sucessão, concedendo a essas pessoas um poder que não era recebido, necessariamente, por capacidade ou merecimento. Sobre isso, o próprio casamento tornou-se essencial, já que se um nobre se casasse com alguém que tivesse sido determinado a reinar, o próprio poderia se tornar um soberano. Além disso, o casamento de linhagens também trazia alianças e rivalidades entre famílias, tendo assim uma função política. Logo, é possível perceber que para a nobreza, o matrimônio servia como um instrumento que construía a sua união com o poder, ou melhor, que tinha o poder de lhes conceder poder, sendo do tipo público ou privado. (DUBY, 1989, p.38)

Outro fator importante, é que o casamento tinha o poder de sustentar as relações de parentesco e a própria instituição familiar, esta que para a historiadora Régine Pernoud (1997), era a chave necessária para se entender a originalidade do Medievo. Sobre isso, a pesquisadora afirma que a explicação se dava ao perceber que na Idade Média o indivíduo já não tinha tanto valor unitário, como acontecia na cultura grega e romana, pois a unidade social que prevalecia era a da linhagem, a da família, isto é, a união parental. Além disso, ressalta a importância da solidariedade familiar no mundo Medieval, em que o sangue permitia suporte e proteção, podendo em um momento de dificuldade contar com aqueles de sua família, unidos por casamentos e solidificados por seus herdeiros. 


\section{O poder na Idade Média}

\section{Ana Clara Cordeiro de Oliveira}

Além da importância do casamento para o âmbito social e político, o matrimônio também tinha influência na vertente econômica da sociedade em questão, pois um casamento com uma família rica poderia trazer muitos benefícios, sendo um deles o dote que o pai da mulher tinha que oferecer pela mão da mesma, que era entregue ao marido para custear as despesas do matrimônio. Além disso, o casamento também envolvia o objetivo de garantir e preservar o patrimônio fundiário, já que a sociedade era fortemente rural, e a terra era sinônimo de riqueza, sendo comum fazerem parte do dote que a esposa concedia para a família do futuro marido. Com isso, entende-se a normalidade quanto aos casamentos endogâmicos na alta nobreza, pois assim teriam certeza de que os bens reproduzir-se-iam dentro da família.

O matrimônio também tinha poder sobre a questão da herança, já que era necessário um sucessor para perpetuar toda a honra, bens e a descendência da família, isto é, tudo de valor que uma linhagem poderia possuir. Entretanto, esse herdeiro não poderia ser um bastardo, e para que isso acontecesse era preciso um casamento "bom" e oficial. Além disso, a fidelidade da esposa também era indiscutível, sendo considerada como um dos pilares da moral laica, pois como a única certeza parental do filho era com a mãe, a fidelidade tornava-se crucial para que não houvesse corrupções sanguíneas na família. Ao mesmo tempo, como a responsabilidade da herança era dada ao primogênito homem, pois as mulheres no modelo régio eram excluídas da partilha de bens, tornava-se necessário também que a esposa deixasse pelo menos um herdeiro masculino. Um trecho de Georges Duby (1989, p.17) discute essa questão:

Em contrapartida, para a moça, o que se exalta e o que toda uma teia de interditos procura cuidadosamente garantir é a virgindade e, no que diz respeito à esposa, a fidelidade. Porque o desregramento natural desses seres 


\section{O poder na Idade Média}

O poder do matrimônio no Medievo

perversos que são as mulheres comporta o risco, não havendo vigilância, de introduzir no seio da parentela, entre os herdeiros da fortuna ancestral, intrusos, nascidos de outro sangue, clandestinamente semeados, da espécie desses bastardos que os celibatários da linhagem disseminam, com expansiva generosidade, fora da casa ou entre os serviçais.

Portanto, entende-se que o matrimônio tinha um forte poder sobre a sociedade aristocrática, interferindo não só no sistema político, mas social e econômico. Primeiro, o casamento concedia poder político por meio de alianças e rivalidades entre famílias. Segundo, colocava de pé a estrutura de títulos sociais, a instituição familiar, e permitia a um grupo privilegiado a possibilidade de ascensão, ao mesmo tempo que determinava o prestígio de toda uma linhagem, podendo afetar tanto o passado quanto o futuro familiar. Concluindo com o seu poder sobre a perpetuação da herança e, principalmente, no que seria a única fonte de riqueza desde os começos do mundo medieval: a terra (PERNOUD, 1997).

Contudo, retoma-se a ideia inicial discutida nesse artigo: a de que existia uma duplicidade no código matrimonial do Medievo. Esse código estaria pautado na moral laica, de início, e conviveria em paralelo com a moral dos religiosos, tendo a primeira objetivos materiais e a segunda motivações espirituais. Entretanto, como Silvana Vecchio afirmou (1990), ao se analisar a trajetória do matrimônio durante a Idade Média, identifica-se que realmente houve uma supremacia do modelo religioso, devido a sua sacralização. Todavia, não significando um apagamento dos costumes laicos, mas que a partir dos anos foi havendo uma lenta junção dos dois modelos, pois acabaram convergindo em relação à desconfiança e desprezo dirigido às mulheres. 


\section{O poder na Idade Média}

Ana Clara Cordeiro de Oliveira

\section{Conclusão}

Com isso, é mais que explicada a escolha do matrimônio como o tema do artigo, pois o mesmo é um exemplo de poder que abre espaço para análises em campos mais abrangentes, repercutindo nas questões do masculino e feminino; em temáticas sobre sexualidade na Idade Média; ou então em relação à estrutura de parentesco, heranças e entre outras possibilidades que não foram apresentados nesse trabalho. É uma abordagem discutida e respondida por pesquisadores que se comprometem com o aprofundamento das informações, como o próprio historiador Georges Duby, tão citado nesse artigo, fez ao fugir de um olhar simplista que foque em grandes estruturas e instituições políticas.

Todavia, concomitante às preocupações de Georges de Duby (1989), esse artigo também se comprometeu em chamar a atenção sobre os perigos que existem ao se estudar a temática do matrimônio nesse contexto, já que a maior parte das fontes à que os historiadores têm acesso são documentos oficiais e escritas de religiosos, que em geral, traziam um cenário do ideal e sonhado, provavelmente diferente do vivido. Lembrando que muitas dessas fontes foram escritas por celibatários, logo, dificilmente saberiam relatar a realidade do cotidiano de um casamento.

Além disso, parafraseando Georges Duby, a Idade Média era a idade dos homens, portanto, a questão do apagamento da voz da mulher sobre o casamento Medieval, e infelizmente em muitos outros temas, também precisa ser considerado, já que torna incompletas e refutáveis algumas informações obtidas a partir de fontes exclusivamente masculinas sobre a temática, diante do que as únicas vozes escutadas eram as dos homens.

Apesar das dificuldades que se encontram ao analisar o casamento e seu poder 


\section{O poder na Idade Média}

O poder do matrimônio no Medievo

na Baixa Idade Média europeia cristã, ainda assim a instituição matrimônio no Medievo foi um instrumento de poder utilizado pelas autoridades da época para assegurar o controle do feminino pelos homens, para disciplinar as temidas mulheres e suas tendências pecaminosas. Ademais, o casamento foi usado como mecanismo para oficializar a procriação, ordenar a desigualdade proclamada pela narrativa mítica da criação, e por fim, para organizar as relações de parentesco e hereditariedade, papéis que foram essenciais na construção da Idade Média.

Dessa maneira, para concluir o artigo é interessante refletir sobre a ideia abordada no início, que entendendo o sistema Medieval é possível realizar uma assimilação com a moralidade repercutida nos discursos conservadores brasileiros, em que é fortemente presente a influência dos códigos matrimoniais da Baixa Idade Média, inclusive a perpetuação das imagéticas femininas construídas com base em Lilith e Eva, e em maior fervor a da Virgem Maria, pois segundo Charles Boxer (1997, p.129) "a popularidade e fervor do culto da Virgem não perdeu em nada com a emigração através dos Sete Mares e, se possível, teve tendência a aumentar".

Nesse sentido, podemos fazer uma associação entre o papel do homem, a terra como bem econômico, a importância da hereditariedade, com muitos outros exemplos, que não desapareceram nos séculos passados, mas que estão vivos, e que fazem parte das relações culturais brasileiras, pois, como afirmava Hilário Franco Júnior (2008), não era falar de uma Idade Média no Brasil, mas de um sistema de valores Medievais no país. Com isso, reafirmo a importância da discussão e leitura sobre a temática por brasileiros. 


\section{O poder na Idade Média}

Ana Clara Cordeiro de Oliveira

\section{Referências Bibliográficas}

BASTOS, Rodolpho Alexandre Santos Melo. Ressonâncias medievais no feminino contemporâneo: os modelos de feminilidade no medievo e sua relação com a violência contra as mulheres. Mandrágora, 2016.

BÍBLIA. Nova Bíblia pastoral. Tradução de Luiz Gonzaga do Prado. São Paulo: Paulus, 2014.

BÍBLIA DE JERUSALÉM. Coríntios. São Paulo: Editora Paulus, 2004.

BOXER, Charles R. O culto de Maria e a prática da misoginia. Lisboa, Livros Horizonte, 1977.

CASAGRANDE, Carla. A mulher sob custódia. Porto: Afrontamento, 1990.

CHARTIER, Roger. A História Cultural: Entre Práticas e Representações. Rio de Janeiro: Bertrand, 1990.

DUBY, Georges. Eva e os padres. São Paulo: Companhia das Letras, 2001. Idade média, idade dos homens. São Paulo: Companhia das Letras, 1989.

- O cavaleiro, a mulher e o padre: o casamento na França feudal. Lisboa: Publicações Dom Quixote, 1988

FRANCO JÚNIOR, H. Raízes medievais do Brasil. São Paulo: Revista USP, 2008.

KLAPISCH-ZUBER, Christiane. Masculino/feminino. In: Le Goff, Jacques; SCHMITT, Jean Claude (coord.). Dicionário Temático de Ocidente Medieval. Bauru, SP: EDUSC, 2006.

MALORY, Thomas. La muerte de Arturo. Madrid: Siruela, 2005.

MARTIN PEREZ. Livro das Confissões. Edição semidiplomática de José Barbosa MACHADO e Fernando TORRES MOREIRA. Edições Pena Perfeita 2005-2006, 2vols. 


\section{O poder na Idade Média}

O poder do matrimônio no Medievo

PERNOUD, Régine. Luz sobre a Idade Média. Publicações Europa-América: Lisboa, 1997.

SOUZA, José Antônio C. R. de. O pensamento gelasiano a respeito das relações entre Igreja e o império romano-cristão. Porto Alegre: Edipuers, 1995.

VECCHIO, S. A boa esposa. In: DUBY, G.; PERROT, M. História das mulheres no Ocidente. Lisboa: Afrontamento, 1990.

ROSSIAUD, Jacques. Sexualidade. In: LE GOFF, Jacques; SCHMITT, Jean-Claude (coord.). Dicionário Temático do Ocidente Medieval. Vol. II Bauru, SP: EDUSC, 2006. 